\title{
Pengaruh Pekerjaan Terhadap Tajam Penglihatan
}

\author{
Sudirman \\ Email: sudirman@uniqhba.ac.id \\ Dosen Prodi Pendidikan Matematika FKIP UNIQHBA
}

\begin{abstract}
ABSTRAK
Penurunan tajam penglihatan selain dipengaruhi oleh katarak juga disebabkan oleh penyakit yang mempengaruhi retina. Pekerjaan yang banyak terpapar sinar matahari tanpa pelindung, juga diperkirakan mempengaruhi tajam penglihatan. Penduduk di wilayah Puskesmas Kopang memiliki keadaan sosial ekonomi dan tingkat pendidikan yang masih rendah. Penelitian ini bertujuan untuk mengetahui pengaruh pekerjaan terhadap tajam penglihatan. Penelitian ini dilakukan di Puskesmas Kopang, Lombok Tengah mulai April sampai Mei 2018. Rancangan penelitian adalah cross sectional dengan jumlah sampel 73 responden yang berumur 40 tahun keatas yang diambil secara simple random sampling. Pengukuran tajam penglihatan menggunakan Tumbling E, data pekerjaan diambil dengan wawancara langsung mengenai aktivitas responden dari jam 10.00 sampai 14.00 wita tanpa pelindung mata, untuk mengetahui signifikasi data di analisis menggunakan uji Mann - Whitney menggunakan program SPSS versi 16.0 dengan tingkat kepercayaan $95 \%(\alpha=0.05)$. Berdasarkan hasil analisis statistik, pekerjaan berpengaruh secara signifikan $(\mathrm{P}<0.05)$ terhadap tajam penglihatan yakni sebesar $41.1 \%$, artinya pekerjaan luar ruangan tanpa pelindung dapat menyebabkan terjadinya penurunan tajam penglihatan sebesar $41.1 \%$.
\end{abstract}

Kata Kunci: Pekerjaan, Tajam Penglihatan.

\begin{abstract}
Low vision affected by cataracts is also caused by retina disease. Work that is exposed to a lot of sunlight without protection, is also thought to affect sharp eyesight.. The population in the Kopang Health Center area has low of socioeconomic and education. The aim of this study was to evaluate the influence of work to visual acuity. This study is non experimental with crosssectional method and was carried out involving 73 respondents as sample aged 40 years, who were taken by simple random sampling in Kopang Primary Health Care, Central Lombok. Statistical analysis shows, this study revealed that the work was significantly $(\mathrm{P}<0.05)$ influenced to visual acuity was equal to $41.1 \%$, it mean that work outside was found in $42.5 \%$ of those with low vision.
\end{abstract}

Keywords: Pekerjaan, Visual Acuity.

\section{A. LATAR BELAKANG}

Pemeriksaan tajam penglihatan merupakan pemeriksaan fungsi mata. Gangguan penglihatan memerlukan pemeriksaan untuk mengetahui sebab kelainan mata yang mengakibatkan turunnya tajam penglihatan. Untuk mengetahui tajam penglihatan seseorang dapat dilakukan pengukuran dengan menggunakan kartu Snellen (Snellen Chart) atau tumbling E [1]. Penyebab tersering turunnya tajam penglihatan adalah katarak, parut kornea yang mempengaruhi jalur penglihatan dan penyakit-penyakit yang mempengaruhi retina [2]. Degenarasi makular, diabetes [2] dan hipertensi [3] adalah penyakit yang bisa mempengaruhi retina. Pekerjaan yang banyak terpapar sinar matahari mengakibatkan terkena sinar ultraviolet [4], sinar ultraviolet diperkirakan mempengaruhi ketajaman penglihatan.

Diabetes Mellitus (DM) adalah salah satu penyakit yang diperkirakan mempercepat proses turunnya tajam penglihatan, karena DM dapat mempengaruhi kejernihan lensa akibat peningkatan kadar gula darah dalam lensa [5]. 
Selain pada lensa, diabetes mellitus juga dapat menimbulkan komplikasi pada retina yang disebut retinopati diabetik, retinopati diabetik mengakibatkan terjadi kerusakan pembuluh darah retina atau lapisan saraf mata sehingga mengalami kebocoran. Akibatnya, terjadi penumpukan cairan (eksudat) yang mengandung lemak serta pendarahan pada retina [6].

Selain diabetes, hipertensi diperkirakan menjadi salah satu penyebab turunnya tajam penglihatan. Hipertensi atau darah tinggi dialami hampir sebagian besar penderita diabetes, hipertensi merupakan salah satu komplikasi dari diabetes, diperkirakan muncul menyertai komplikasi lainnya yaitu turunnya tajam penglihatan. Retina merupakan bagian tubuh yang secara langsung bisa menunjukkan adanya efek dari hipertensi terhadap arteriola (pembuluh darah kecil).

Faktor lainnya yang diperkirakan bisa memicu terjadinya turunnya tajam penglihatan adalah pekerjaan, yaitu pekerjaan di luar ruangan yang memungkinkan lebih sering terkena paparan sinar matahari. Pekerjaan seseorang yang banyak terpapar sinar matahari seperti petani, nelayan dan buruh lebih berisiko terkena penurunan tajam penglihatan [7]. Hasil penelitian Ziahulhak [4] di Kalimatan Timur menunjukkan bahwa, pekerjaan dan aktifitas memiliki hubungan yang secara statistik bermakna dengan katarak, yang ditandai dengan turunnya ketajaman penglihatan (low vision).

Topografi wilayah Puskesmas Kopang terdiri dari, lereng/bukit, dan dataran, mayoritas pekejaannya sebagai petani $(42.79 \%)$, persentase penduduk miskin (pra sejahtera) sebesar $37.41 \%$ dan $41.83 \%$ penduduknya belum pernah sekolah atau tidak tamat Sekolah Dasar (SD) [8] dan prevalensi katarak di Lombok sebesar $11.6 \%$ [9]. Data diatas menggambarkan bahwa penduduk disekitar Puskesmas Kopang memiliki keadaan sosial ekonomi dan tingkat pendidikan yang masih rendah, hal inilah yang menyebabkan kurangnya akses informasi dan pengetahuan kesehatan pada masyarakat, sehingga akan menimbulkan ketidakberdayaan dan ketidaktahuan masyarakat tentang kesehatan mata.

Puskesmas Kopang merupakan salah satu dari 2 (dua) puskesmas yang ditunjuk oleh pemerintah pusat dan daerah melalui Dinas Kesehatan NTB yang bekerjasama dengan Helen Keller Internasional untuk dijadikan proyek percontohan diselenggarakannya kegiatan operasi mata sejak tahun 2005. Pada tahun 2008 dari 1739 pasien yang memeriksakan diri di Puskesmas Kopang, 1464 orang dinyatakan positif menderita katarak, sebanyak $35.60 \%$ ditunda operasinya karena menderita diabetes dan $31.81 \%$ karena hipertensi. Hal ini berarti, tingginya angka kejadian katarak diatas diduga disebabkan oleh penyakit diabetes mellitus dan hipertensi.

Berdasarkan uraian diatas, penurunan tajam penglihatan selain dipengaruhi oleh katarak juga disebabkan oleh penyakit yang mempengaruhi retina, diabetes dan hipertensi adalah penyakit yang mempengaruhi retina. Selain itu juga pekerjaan yang banyak terpapar sinar matahari, juga diperkirakan mempengaruhi tajam penglihatan. Penduduk di wilayah Puskesmas Kopang memiliki keadaan sosial ekonomi dan tingkat pendidikan yang masih rendah, hal ini akan menyebabkan kurangnya akses informasi dan pengetahuan tentang kesehatan mata sehingga gangguan penyakit mata akan meningkat.

Tujuan dari penenilitian ini adalah untuk mengetahui pengaruh diabetes mellitus, hipertensi, interaksi diabetes mellitus dan hipertensi serta mengetahui pengaruh pekerjaan terhadap tajam penglihatan di Puskesmas Kopang. Hasil penelitian ini diharapkan Bagi masyarakat, dapat memberikan sumbangan pengetahuan, sehingga dapat dimanfaatkan dalam upaya pencegahan penurunan tajam penglihatan sedini mungkin di masyarakat.

\section{B. METODE PENELITIAN}

1. Rancangan Penelitian 
Rancangan penelitian ini adalah penelitian potong lintang (cross sectional) dengan sistem simple random sampling single proportion.

\section{Populasi dan Sampel Penelitian}

Populasi penelitian ini adalah seluruh pasien yang melakukan pemeriksaan mata di Puskesmas Kopang Lombok Tengah pada tahun 2017, yakni sebesar 343 orang dengan jumlah sampel 73 responden yang berumur 40 tahun keatas.

\section{Tempat dan Waktu Penelitian}

Penelitian ini dilakukan di Puskesmas Kopang Kabupaten Lombok Tengah dan berlangsung dari bulan April 2018 sampai Mei 2018.

\section{Tehnik pengumpulan data}

a. Mencatat identitas subyek penelitian, meliputi nama, alamat dan usia serta dilakukan pengisian formulir penelitian secara lengkap sesuai alur penelitian yang telah ditentukan.

b. Meminta responden untuk menutupi bagian mata kirinya (Ocular Sinistra) dengan menggunakan telapak tangan kirinya tetapi jangan ditekan. Memposisikan telapak tangan responden seolah-olah memegang telur dalam genggamannya kemudian tekapkan ke bagian mata yang akan di tes terlebih dahulu.

c. Menggunakan tali untuk mengukur 6 meter yang memiliki simpul dibagian tengah (jarak 3 meter) kemudian mempersilahkan responden untuk duduk atau berdiri dengan jarak 6 meter berhadapan dari tempat petugas lapangan. Posisi responden yang duduk atau berdiri harus membelakangi matahari atau cahaya (tidak menyilaukan mata responden).

d. Menjelaskan bahwa responden harus menunjukkan arah sesuai dengan arah simbol E tersebut (ke atas, ke bawah, ke kiri atau ke kanan). Tumbling $\mathrm{E}$ ini dibuat selain untuk orang yang bisa membaca juga untuk orang yang tidak bisa membaca, karena cukup memberitahu arah kaki dari huruf $\mathrm{E}$ tersebut

e. Responden dikatakan bisa menjawab dengan benar jika responden sanggup menjawab 4 pertanyaan dengan benar secara berturut-turut atau jika responden sanggup menjawab 5 dari 6 pertanyaan dengan benar, atau jika responden sanggup menjawab 6 dari 8 pertanyaan dengan benar [10].

f. Jika responden bisa menjawab benar pada jarak 6 meter dengan ukuran tumbling E kecil (18) maka ukuran visus (ketajaman penglihatan) responden adalah 6/18. Tetapi apabila tidak memenuhi kriteria benar diatas dilanjutkan dengan pengukuran visus $6 / 60$.

g. Jika responden bisa menjawab benar pada jarak 6 meter dengan ukuran tumbling E besar (60) maka ukuran visus (ketajaman penglihatan) responden adalah 6/60, tetapi Jika responden tidak dapat melihat huruf $\mathrm{E}$ besar (60) dari jarak 6 meter, maka peneliti harus maju ke jarak 3 meter dan melakukan tes ketajaman penglihatan dengan huruf $\mathrm{E}$ besar (60).

h. Jika responden bisa menjawab benar pada jarak 3 meter dengan ukuran tumbling E besar (60) maka ukuran visus (ketajaman penglihatan) responden adalah $3 / 60$, tetapi Jika responden tidak dapat melihat huruf $\mathrm{E}$ besar (60) dari jarak 3 meter, maka peneliti harus maju ke jarak 1 meter dan melakukan tes ketajaman penglihatan dengan huruf $\mathrm{E}$ besar (60) atau melakukan tes menghitung jari.

i. Jika responden bisa menjawab benar pada jarak 1 meter dengan ukuran tumbling E besar (60) atau bisa menjawab benar dengan menghitung jari maka ukuran visus (ketajaman penglihatan) responden adalah $1 / 60$, 
tetapi Jika responden tidak dapat melihat huruf E besar (60) atau menghitung jari dari jarak 1 meter, maka peneliti harus melakukan tes persepsi cahaya untuk mengetahui reaksi pupil responden dengan menggunakan senter, caranya dengan mengarahkan cahaya senter dari atas, bawah, kiri dan kanan.

j. Jika responden bisa menjawab benar arah senter setelah dilakukan tes reaksi pupil, maka ukuran visus responden adalah PL(+) (Positif Perception Light). Tetapi apabila tidak bisa menjawab benar arah senter setelah dilakukan tes reaksi pupil, maka ukuran visus responen adalah PL (-) (Negatif Perception Light). Biasanya kalau ukuran visus responden PL (-) diperkirakan sarafnya sudah rusak, sehingga sulit disembuhkan.

k. Bila pengukuran visus untuk melihat reaksi pupil sudah selesai maka dilanjutkan pengukuran visus untuk mata kanan (Ocular Dextra).

1. Jika ditemukan visus kurang dari $6 / 18$ maka responden tersebut diperkirakan mengalami penurunan ketajaman penglihatan.

m. Setelah pengukuran visus selesai, selanjutnya dilakukan tes laboratorium untuk memeriksa glukosa darah dan Tekanan darah. Tekanan darah diukur pada posisi duduk sebanyak tiga kali pengukuran pada rentang 10 menit.

\section{Analisa Data}

Hasil penelitian diuji dengan Mann Whitney test yang merupakan uji alternatif dari uji $t$ - test independent jika distribusi data tidak normal. Pengolahan dan analisa data menggunakan bantuan program SPSS versi 16.0 dengan tingkat kepercayaan $95 \%(\alpha=0.05)$.

\section{Alur Penelitian}

Gambar 1 menunjukkan alur penelitian ini.

\section{HASIL DAN PEMBAHASAN}

Berdasarkan Gambar 2 dapat diartikan bahwa responden yang bekerja diluar ruangan dari jam 10.00 sampai 14.00 Wita tanpa menggunakan pelindung sinar matahari mengalami penurunan tajam penglihatan sebesar 41.1\%. Pengaruh antara pekerjaan dengan tajam penglihatan berdasarkan hasil analisis statistik ternyata berpengaruh secara signifikan $(\mathrm{p}<0.05)$, dengan Odd Ratio $(O R)=6.735$ dan Cinfidence Interval $(C I)=2.331-19.459$, artinya ada hubungan yang erat antara pekerjaan terhadap tajam penglihatan, pekerjaan luar ruangan yang dilakukan pada jam 10.00 sampai 14.00 tanpa pelindung sinar matahari besar kemungkinannya mengalamai resiko penurunan tajam penglihatan sebesar $41.1 \%$.

Hasil penelitian Ziahulhak [4] di Kalimatan Timur menunjukkan bahwa, pekerjaan dan aktifitas memiliki hubungan yang secara statistik bermakna dengan katarak. Berdasarkan jumlah responden 753 orang, ditemukan terjadinya katarak lebih banyak pada aktifitas luar ruangan saat siang hari $(\geq 5 \mathrm{jam} / \mathrm{hari} 34.1 \%)$ dibandingkan dengan aktivitas dalam ruangan $(<5$ jam/hari 26.4\%). Menurut Sirlan [11] salah satu faktor yang diperkirakan mempengaruhi kondisi ini adalah faktor lingkungan berupa paparan sinar ultraviolet (UV) yang tinggi, suatu kondisi yang umum ditemukan di negara-negara berkembang. Sitompul [7] menambahkan, gangguan penglihatan bisa mengancam orang-orang yang kesehariannya bekerja banyak terpapar sinar matahari karena sinar ultraviolet dari matahari bisa menyebabkan penurunan tajam penglihatan. Lebih lanjut dia mengatakan, pekerjaan seseorang yang banyak terpapar sinar matahari, seperti petani, nelayan dan buruh, bahkan bagi mereka yang sering sekali menyetir mobil tanpa 


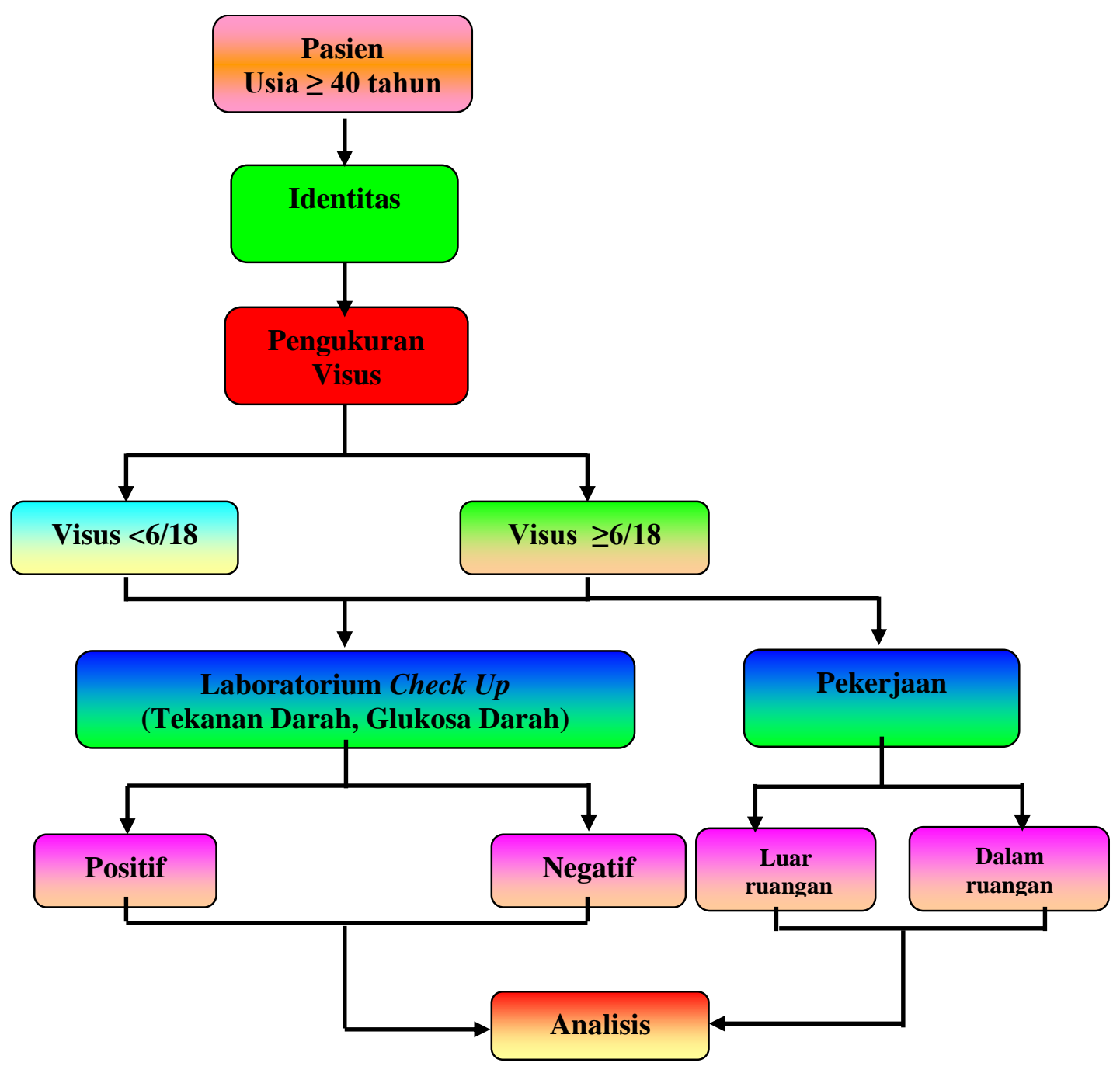

Gambar 1. Alur Penelitian

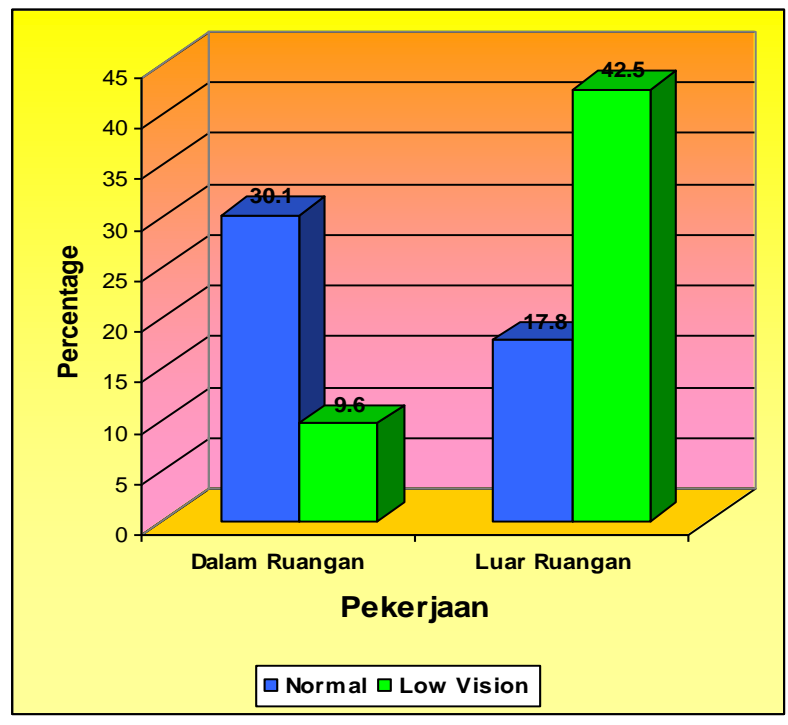

Gambar 2. Grafik Pekerjaan Dengan Tajam Penglihatan 
menggunkan pelindung sinar matahari besar resikonya terkena penurunan tajam penglihatan.

Penelitian epidemiologi menemukan bahwa gangguan penglihatan lebih tinggi ditemukan pada negara-negara tropis yang memiliki karakteristik sebagai daerah dengan paparan sinar matahari tinggi [4]. Penelitian eksperimental di laboratorium menunjukkan bahwa paparan sinar UVA dan UVB pada lensa mata dapat menimbulkan gangguan penglihatan [12][13]. Sinar UVA diketahui dapat menembus lensa hingga ke bagian nukleus sedangkan sinar UVB hanya dapat menembus hingga bagian anterior korteks lensa. Davies dan Truscott [14] menemukan bahwa metabolit triptofan di dalam lensa yang berperan sebagai $U V$ filter, memiliki kemampuan absorpsi maksimal pada panjang gelombang $365 \mathrm{~nm}$ yang termasuk dalam spektrum panjang gelombang sinar UVA. Paparan sinar UVA terhadap lensa dapat menimbulkan gangguan pada struktur protein dan plasma membran sel [15], inaktivasi enzim glutation reduktase [16] dan menurunkan aktivitas enzim katalase [17], yang akan diikuti oleh pembentukan agregasi protein dan bisa menyebabkan terjadinya kekeruhan pada lensa.

Efek sinar UVA terutama terjadi pada nukleus lensa timbul pada usia di atas 40 tahun [18][19]. UV filter terutama 3OHKyn (3hydroxykynurenine) yang merupakan metabolit triptopan bersifat tidak stabil sehingga mudah terurai menjadi $\alpha, \beta$-ketoalkenes kemudian berikatan dengan crystallin [20]. Kemampuan $\alpha, \beta$-ketoalkenes sebagai produk deaminasi 3OHKyn untuk berikatan dengan crystallin dapat dihambat oleh glutation dan NADPH [20]. Saat usia mencapai 40 tahun, kadar glutation di nukleus lensa akan menurun hingga berada di bawah $1 \mathrm{mM}$. Kadar glutation ini berkurang akibat terbentuknya penghalang yang memisahkan korteks (lokasi produksi glutation) dengan nukleus sehingga sirkulasi glutation ke arah nukleus menjadi terhambat [18][19]. Akibatnya, ikatan antara $\alpha, \beta$-ketoalkenes dan crystallin akan meningkat, menyebabkan agregasi protein lebih lanjut di nukleus lensa.
Ikatan $\alpha, \beta$-ketoalkenes dan crystallin akan menyerap sinar UVA kemudian menimbulkan reaksi oksidatif lebih lanjut di nukleus lensa [21]. Modifikasi protein lensa di nukleus akan tampak berupa perubahan warna nukleus menjadi kuning kecoklatan atau kehitaman (brunescent) [18][19][21] sehingga berpengaruh terhadap tajam penglihatan dan kalau tidak ditangani bisa menyebabkan terjadinya kebutaan.

\section{KESIMPULAN}

Berdasarkan hasil dan pembahasan dapat disimpulkan bahwa pekerjaan diluar ruangan dari jam 10.00 sampai 14.00 Wita tanpa pelindung sebesar $41.1 \%$ mempengaruhi tajam penglihatan.

\section{DAFTAR PUSTAKA}

[1] Fitriani, D.G., 2009. Tingkat Kepuasan Pasien Setelah Operasi Katarak Dengan Metode SICS di Lombok. Tesis. Program Studi Ilmu Penyakit Mata, Fakultas Kedokteran, Universitas Indonesia. Jakarta.

[2] Guyton AC, Hall JE., 1996. Mata I. Sifat Optik Mata. Dalam: Guyton AC, penyunting. Buku Ajar Fisiologi Kedokteran edisi 9. Jakarta; Penerbit buku Kedokteran EGC; 779.

[3] Ocampo V, 2008. Cataract, Senile. (Online) Available on: http://www.emedicine.com/oph/. [Accessed: 2009 December 25].

[4] Ziahulhak, S.R., 2007. Asosiasi katarak dan Pterygium di Kalimantan Timur. Tesis. Program Studi Ilmu Penyakit Mata, Fakultas Kedokteran, Universitas Indonesia. Jakarta.

[5] Rosenfeld S. and Blecher MH., 2006. Anatomy. In: Rosenfeld S, editors. Lens \& Cataract. 2006-2007. San Fransisco; American Assosciation of Ophtalmology; 2006. 
[6] Antonetti1 DA, Alistair JB, Sarah KB, Willard MF, Thomas WG, Leonard SJ, Mark K, Scot RK, Kyle K, Kathryn FL, Christopher CN, Patrick GQ, Lakshman S, Ian AS., 2006. Retinopaty Diabetic. (Online)

(http://kireihimee.blogspot.com/retinopatidiabetes-jurnal.html). Diakses: 25 Januari 2010.

[7] Sitompul, R., 2009. Mata. (Online) (http://rohmatulumah.blog.friendster.com). Diakses : 25 Januari 2010.

[8] BPS, 2008. Badan Pusat Statistik Kecamatan Dalam Angka Dalam Angka. Mataram.

[9] Agustiawan R. 2006. Prevalensi katarak senilis dan hubungannya dengan indeks massa tubuh di pulau Lombok. Tesis. Program Studi Ilmu Penyakit Mata, Fakultas Kedokteran, Universtias Indonesia. Jakarta.

[10] Limburg H., 2004. Manual for Rapid Assessment of Cataract Surgical Services. WHO Prevention of blindness and deafness; Switzerland.

[11] Sirlan F. 2000. Faktor resiko buta katarak usia produktif: Tinjauan khusus terhadap enzim glutaton reduktase dan riboflavin darah - Studi kasus di daerah pantai Sumatera Barat dan Nusa Tenggara Barat. FKUI, 2000. Disertasi.

[12] Azzam N, Levanon D, Dovrat A., 2004. Effects of UV-A radiation on lens morphology and optics. Exp Gerontol, 39: 139.

[13] Meyer LM, Soderberg PG, Dong X, Wegener A., 2005. UVR-B induced cataract development in $C 57$ mice. Exp Eye Res, 81: 389.
[14] Davies MJ, Truscott RJW., 2001. Photooxidation of protein and its role in cataractogenesis. J Photochem Photobiol, 63: 114.

[15] Weinreb O, Dovrat A, Dunia I, Benedetti EL, Bloemendal H., 2001. UV-A related alterations of young and adult lens water insoluble $\alpha$ crystalline, plasma membranous and cytoskeletal proteins. Eur J Biochem 2001; 268: 536.

[16] Linetsky M, Chemoganskiy VG, Hu F, Ortwerth BJ., 2003. Effect of UVA light on the activity of several aged human lens enzymes. Invest Ophthalmol.Vis Sci. 44: 264.

[17] Giblin FJ, Leverenz VR, Padgaonkar VA, Unakar NJ, Dang L, Lin RL., 2002. UVA light in vivo reaches the nucleus of the guinea pigs and produces deleterious oxidative effects. Exp Eye Res, 75: 445.

[18] Truscott RJW, McNulty R, Taylor L, Hood B, Aquilina JA, Takikawa O. 2002. Tryptophan metabolism, aging and cataract. International Congress Series 1233.185-90.

[19] Truscott RJW., 2005. Age related nuclear cataract, oxidation is the key. Exp Eye Res; 80: 709-25.

[20] Taylor LM, Aquilina A, Jamie JF, Truscott RJW., 2002. UV filter instability: consequences for the human lens. Exp Eye Res. 75: 165-75.

[21] Chen YC, Reid GE, Simpson RJ, Truscott RJW. 1997. Molecular evidence for involvement of alpha crystalline in the colouration/crosslinking of crystalline in age related nuclear cataract. Exp Eye Res; 65: 835-40. 